\title{
THE EFFECT OF LENGTH OF TIME PERIOD CONSIDERED IN ESTIMATING GROUNDWATER RECHARGE WITH A SOIL WATER BUDGET MODEL
}

\author{
R. P. DE SILVA* \\ Department of Agricultural and Plantation Engineering, \\ The Open University, Nawala, Nugegoda
}

(Received: 21 August 2001 ; accepted: 09 December 2002)

\begin{abstract}
The rate of replenishment of water table (or rate of groundwater recharge) is a key issue one needs to know in developing groundwater resources. The soil water budget method is often used to estimate this rate of recharge. The need to use daily climatic data (rather than weekly or monthly data) in the soil water budget has been shown by Howard \& Lloyd. ${ }^{6}$ However, no recommendations exist on the minimum duration necessary for precise soil water budgeting. This study attempts to find a suitable answer to this question, choosing Angunakolapelessa in the dry zone of Sri Lanka and Silsoe in UK as study locations. The results of the study show that it is good practice to use as many years of daily water balance data as possible. If this is not possible, climatic data for at least 3 years (consisting of a wet year, a dry year and an average year) must be used in order to achieve realistic estimates of recharge.
\end{abstract}

Key Words: Soil water budget, groundwater recharge, time period

\section{Abbreviations \& Notations}

The abbreviations and notations (and where appropriate the units of measurement) used in general in this paper are as follows:

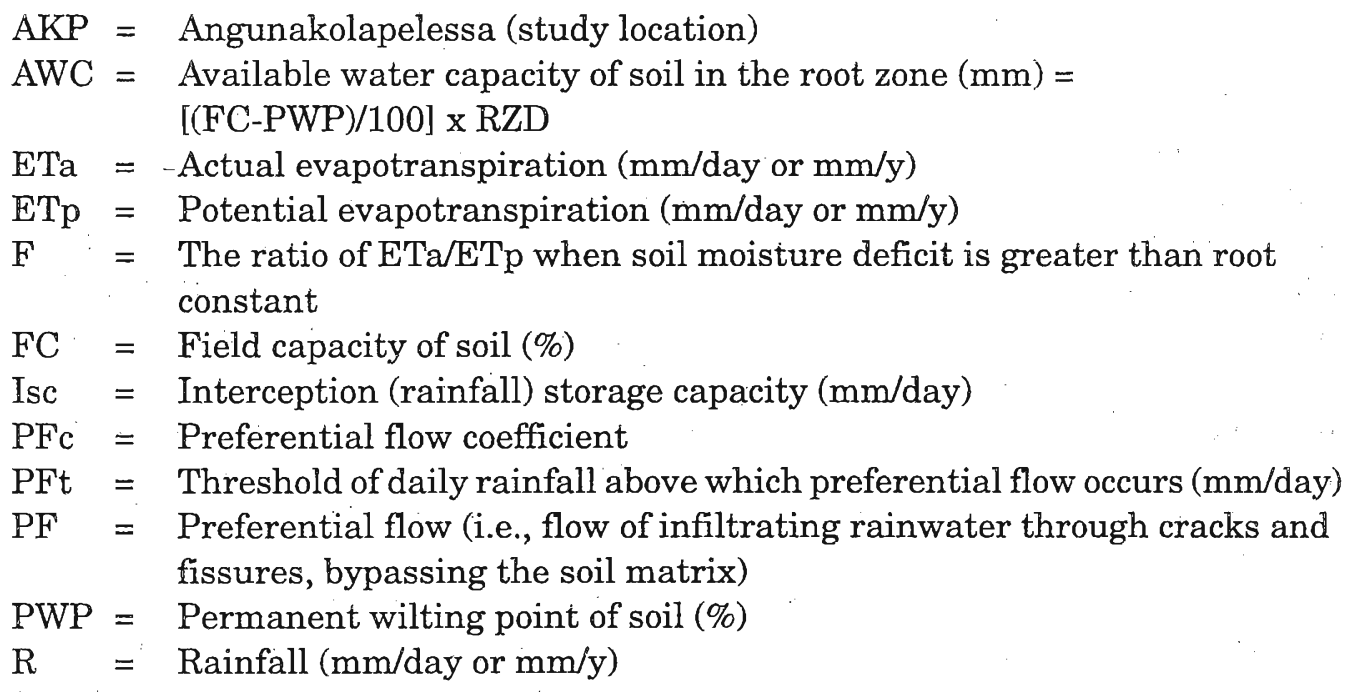




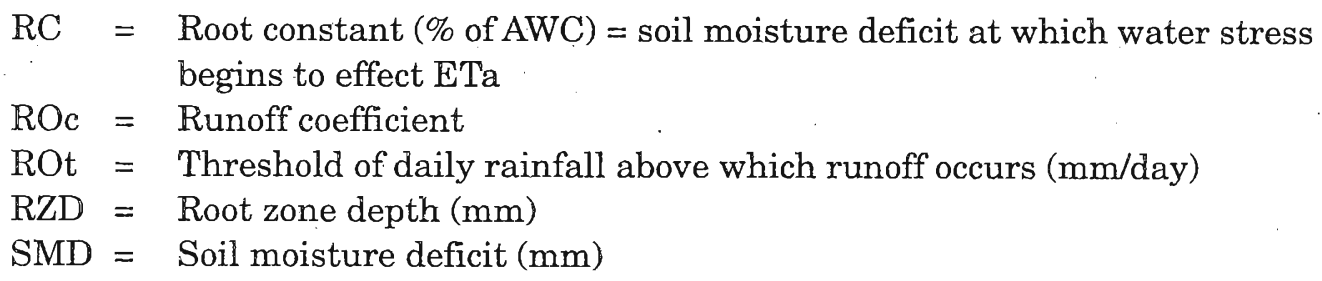

\section{INTRODUCTION}

The ra ${ }^{2} \in$ vi recharge is defined as the rate of replenishment of the water table. A knowledge of the rate of recharge must be available in developing a groundwater source for domestic, industrial or agricultural purposes, as this parameter determines the rate of safe yield that can be abstracted from the groundwater reservoir. ${ }^{1}$

It is very difficult to determine the rate of recharge to the water table accurately. The best hope is to arrive at a reasonable estimate. There are a few commonly used methods of estimating recharge. ${ }^{2,3,4}$ They are (a) the use of lysimeters (b) soil water balance models (c) water table fluctuation method (d) catchment water balance method (e) numerical modelling of the unsaturated zone (f) zero flux plane method (g) Darcy method (h) Tritium method and (i) Chloride method.

Of the above methods, the soil water balance method is a simple and an easy to use one in most climatic conditions and quite often is the only available method for a particular climatic condition..$^{5}$ In this method, a volume balance for the water entering and leaving the root zone and change in soil moisture storage is carried out and recharge $(\mathrm{Re})$ is estimated as;

$$
R_{e}=\left(P-I-R O-E T_{a}-P F\right)+(P F) \pm \Delta S
$$

Here $\mathrm{P}$ is precipitation, $\mathrm{I}$ is interception of rainfall by vegetation, $\mathrm{RO}$ is run off, $\mathrm{PF}$ is preferential flow, ETa is actual evapotranspiration and $\triangle \mathrm{S}$ is change in soil moisture storage. It is important to note that the first term within brackets is the matrix flow (MF) and the second term within brackets is the preferential flow (PF). Now, the estimation of actual evapotranspiration is affected by matrix flow, which in turn is affected by the amount of preferential flow. Therefore, estimates of recharge (which are affected by estimates of actual evapotranspiration), are affected as a result of preferential flow (i.e., for estimates of recharge to be affected by preferential flow, it is not necessary for preferential flow paths to be effective for deeper depths, but depths just around root zone are sufficient).

If the balance is carried out annually (especially from the end of the rainy season to the same time the following year), the change in soil moisture storage is negligible (as moisture content at both times will be at field capacity). Therefore, equation 1 can be reduced to; 


$$
R_{e}=\left(P-I-R O-E T_{a}-P F\right)+(P F) \pm \Delta S
$$

Usually, recharge estimated by equation (2) is computed for a few years (normally one or two years) with a daily time step. ${ }^{6}$ However, since rainfall varies significantly from year to year (especially in a country like Sri Lanka), the resulting estimates of annual recharge also vary annually. This paper studies the effect of the length of time period considered on the reliability of estimating recharge with a soil water budget model.

\section{METHODS AND MATERIALS}

- The methodology adopted in general was to estimate recharge for different time periods (for different locations) and compare the estimates. The specific steps of the methodology adopted were as follows:

(a) Select suitable study locations.

(b) Collect relevant data (i.e., daily rainfall and pan evaporation for a number of years, information on rainfall interception and runoff).

(c) Experimentally determine the field capacity and permanent wilting point of soil and also observe the type of vegetation and depth of roots at each location.

(d) Form a soil water balance model to estimate recharge.

(e) Estimate recharge with different time periods as the length of time period considered and arrive at suitable conclusions.

Study locations: The study locations chosen in this research project are Silsoe in Bedfordshire in England, UK and Angunakolapelessa in the southern dry zone of Sri Lanka (Fig.1). These two locations were chosen because of the availability of long term rainfall and evaporation data that were needed for the study and also because of the availability of other required data such as field capacity and permanent wilting point of the root zone soil. Table 1 summarises the climatic, vegetative and top soil details at the study locations.

Determination of field capacity, wilting point and other parameters: A summary of climatic data and soil properties at each location is shown in Table 2. Details of climatic data and details of experiments carried out to determine the soil properties in Table 2 are given by de Silva. ${ }^{7}$ The field capacity and permanent wilting point were measured using a pressure plate apparatus as described by de Silva. ${ }^{7}$ 


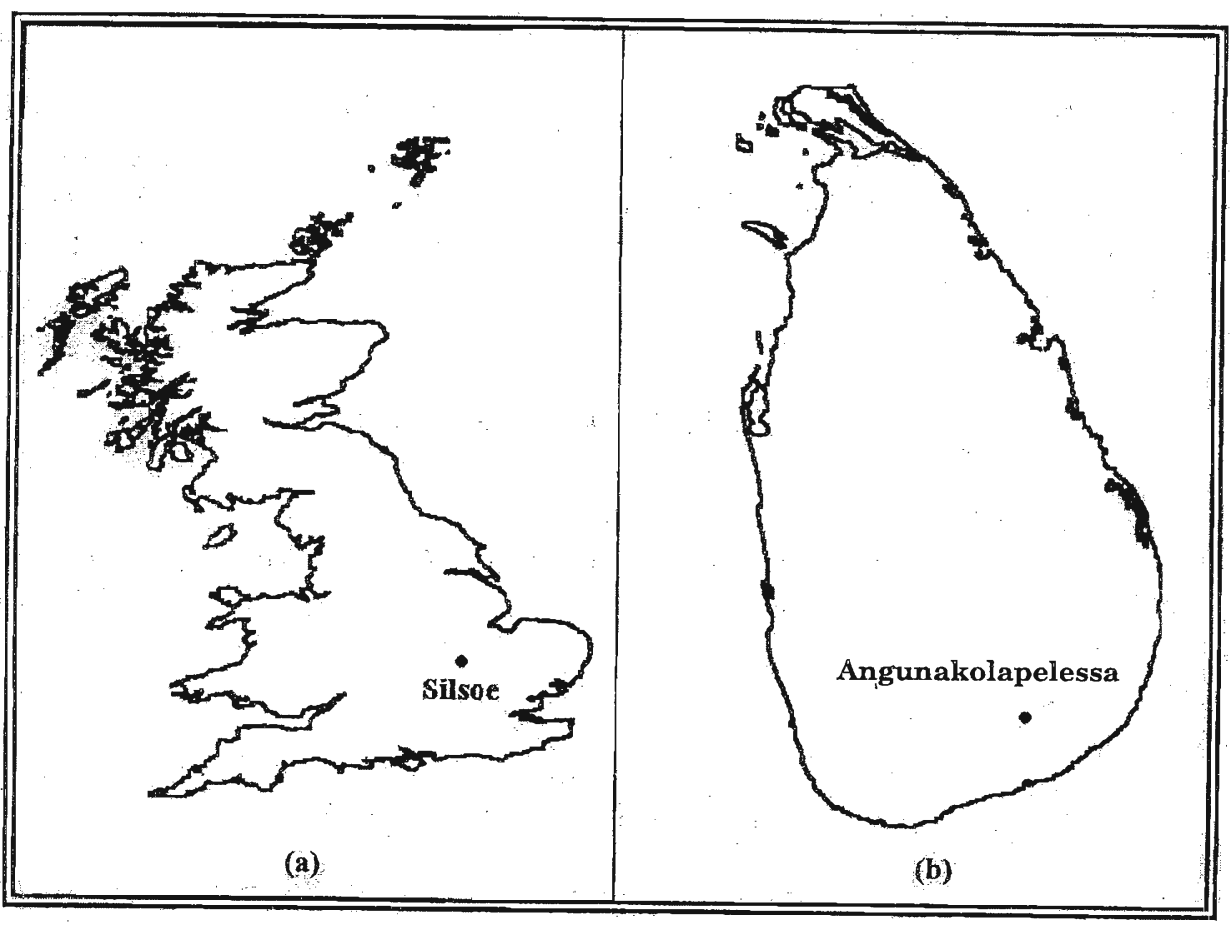

Figure 1: Maps showing the study locations (a) Silsoe in Bedfordshire in the UK and (b) Angunakolapelessa in Sri Lanka

Table 1: Climatic, vegetative and top soil details of the study locations

\begin{tabular}{|c|c|c|c|c|c|}
\hline $\begin{array}{l}\text { Location \& } \\
\text { Country }\end{array}$ & $\begin{array}{c}\text { Mean Annual } \\
\text { Rain } \\
(\mathrm{mm} / \mathrm{y})\end{array}$ & $\begin{array}{c}\text { Mean Annual } \\
\text { Pan Evaporation } \\
(\mathrm{mm} / \mathrm{y})\end{array}$ & Vegetation & $\begin{array}{l}\text { Major } \\
\text { Plant } \\
\text { type }\end{array}$ & $\begin{array}{l}\text { Top soil } \\
\text { (Soil order/ } \\
\text { Group)* }\end{array}$ \\
\hline $\begin{array}{l}\text { Angunakola- } \\
\text { pelessa, } \\
\text { Sri Lanka }\end{array}$ & 1041 & 1868 & $\begin{array}{l}\text { Shrub } \\
\text { jungle }\end{array}$ & $\begin{array}{l}\text { Eraminya } \\
\text { (bush } \\
\text { about } 1.5 \mathrm{~m} \\
\quad \text { tall) }\end{array}$ & $\begin{array}{l}\text { Sandy } \\
\text { Clay } \\
\text { n Loam } \\
\text { (Solonetz) }\end{array}$ \\
\hline Silsoe, UK & 559 & 616 & Grass & Thistle & $\begin{array}{c}\text { Sandy } \\
\text { (Fluvisols) }\end{array}$ \\
\hline
\end{tabular}

\footnotetext{
* Source: Dominant soil groups of the world, based on the FAO-UNESCO Soil Map of the World (could be accessed on the internet at http://www.fao.org or at ftp://ftp.fao.org/agl/agll/wrb/wrbdom.gif)
} 


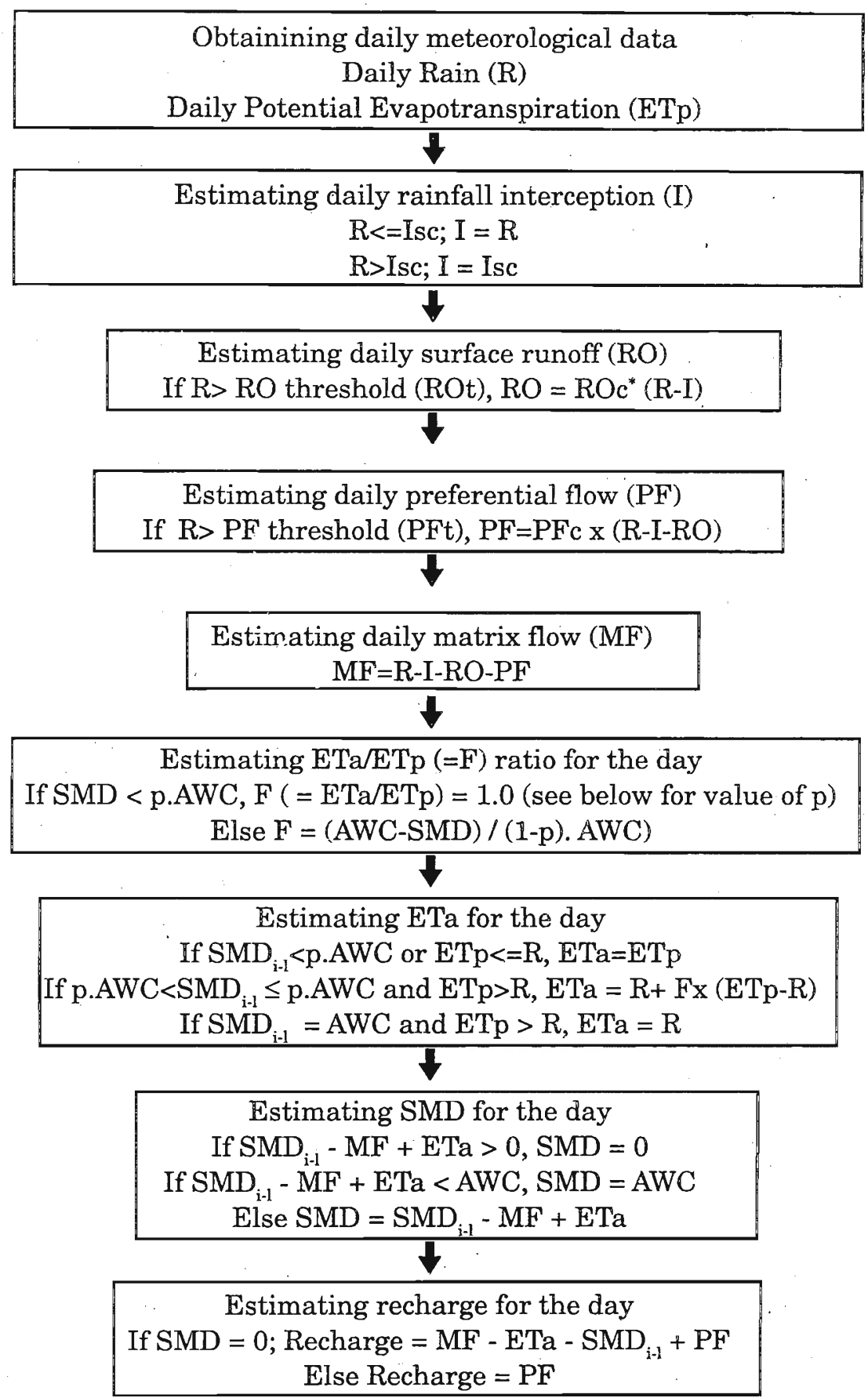

Figure 2: Flow chart of the soil water model used in this study (please refer the list of abbreviations given at the beginning of this paper) 
Table 2: Soil properties and details of data collected at each location of this study.

\begin{tabular}{lcccccc}
\hline $\begin{array}{l}\text { Location and } \\
\text { Country }\end{array}$ & $\begin{array}{c}\text { No. of } \\
\text { sampling } \\
\text { points in } \\
\text { the location }\end{array}$ & $\begin{array}{c}\text { Depth } \\
\text { to } \\
\text { water } \\
\text { table } \\
\text { (m) }\end{array}$ & $\begin{array}{c}\text { No. of years } \\
\text { daily rainfall } \\
\text { and pan } \\
\text { evaporation } \\
\text { data } \\
\text { collected }\end{array}$ & $\begin{array}{c}\text { Root } \\
\text { zone } \\
\text { depth } \\
\text { (m) }\end{array}$ & $\begin{array}{c}\text { Field } \\
\text { Capacity } \\
(\%)\end{array}$ & $\begin{array}{c}\text { Permanent } \\
\text { Wilting } \\
\text { Point(\%) }\end{array}$ \\
\hline $\begin{array}{l}\text { Angunukola- } \\
\text { pelessa, Sri Lanka }\end{array}$ & 12 & $>4.1$ & $16(1976-1991)$ & 0.95 & 20.2 & 12.0 \\
Silsoe, UK & 21 & $>12$ & $28(1962-1989)$ & 1.20 & 22.9 & 12.2 \\
\hline
\end{tabular}

Soil water budget model: The flow chart of the soil water budget model used in this study is shown in Fig. 2. The formation of the model with an explanation of the spreadsheet calculations used to estimate recharge with this model is given by de Silva. ${ }^{7}$

Here, the value of $p$ is equal to the root constant. Values of pan evaporation were converted to values of evapotranspiration using pan co-efficients. ${ }^{2}$ Table 3, below, gives the values of Isc, ROt, ROc, PFt and PFc used for the two locations. These values were obtained from de Silva. ${ }^{7}$

Table 3 : Values for model parameters used for the two locations

\begin{tabular}{lccccc}
\hline & $\begin{array}{c}\text { Isc } \\
(\mathrm{mm} / \mathrm{d})\end{array}$ & $\begin{array}{c}\mathrm{ROt} \\
(\mathrm{mm} / \mathrm{d})\end{array}$ & $\mathrm{ROc}$ & $\begin{array}{c}\mathrm{PFt} \\
(\mathrm{mm} / \mathrm{d})\end{array}$ & $\mathrm{PFc}$ \\
\cline { 2 - 6 } & 1.6 & 12.5 & 0.32 & 10 & 0.075 \\
Angunakolapelessa & 1.6 & 2.0 & 0.01 & 2.0 & 0.01 \\
Silsoe & 1.0 & & & & \\
\hline
\end{tabular}

\section{RESULTS AND DISCUSSION}

Table 4 and Table 6 give the estimates of recharge for Angunakolapelessa and Silsoe respectively, if the budgeting period is considered as one year. (Some studies have suggested that ETa is normally higher than what is estimated in Column 6 of Table 4 for Angunakolapelessa). However, in this study, ETa was estimated as shown in Fig. 2, from the root constant model. ${ }^{1}$ Further, those studies have had water input as irrigation, thus having smaller periods of water shortages for the crops resulting in higher values of ETa. The average recharge values of $80 \mathrm{~mm} / \mathrm{y}$ for Angunakolapelessa and $116 \mathrm{~mm} / \mathrm{y}$ for Silsoe agree with studies on the same areas by Dharmasiri \& Dharmawarden ${ }^{9}$ and by Irving ${ }^{10}$ respectively. This suggests that 
the values of model parameters used in Table 3 are reasonably correct for the two areas of study. Details of how these model parameters were decided are given by de Silva. ${ }^{7}$

As expected, the soil water budget model correctly predicts that at Angunakolapelessa, most components of the hydrological cycle (interception, runoff, evapotranspiration and recharge) are significant (Table 4), but at Silsoe, only evapotranspiration and recharge are significant (Table 6). The reasons for zero runoff at Silsoe is that the soil at the study location is sandy (Table 1) and also the precipitation is low intensity spread over 9 months of the year (except during the summer months). However, at Angunakolapelessa, high intensity rains of shorter duration on hard soils lead to significant amounts of runoff.

Table 4: Yearly estimate of recharge for Angunakolapelessa for the period 1976-1991

\begin{tabular}{lcccccc}
\hline Year & $\begin{array}{c}\text { P } \\
(\text { rain }) \\
(\mathrm{mm})\end{array}$ & $\begin{array}{c}\text { Interception } \\
(\mathrm{mm})\end{array}$ & $\begin{array}{c}\text { Run } \\
\text { off } \\
(\mathrm{mm})\end{array}$ & $\begin{array}{c}\text { ETp } \\
(\mathrm{mm})\end{array}$ & $\begin{array}{c}\text { ETa } \\
(\mathrm{mm})\end{array}$ & $\begin{array}{c}\text { Total } \\
\text { Recharge } \\
(\mathrm{mm})\end{array}$ \\
\hline 1976 & 1020 & 128 & 227 & 2015 & 528 & 137 \\
1977 & 1179 & 148 & 252 & 1691 & 629 & 150 \\
1978 & 993 & 142 & 185 & 1868 & 579 & 87 \\
1979 & 1127 & 163 & 231 & 1746 & 681 & 51 \\
1980 & 1137 & 135 & 244 & 2055 & 644 & 114 \\
1981 & 830 & 120 & 151 & 2136 & 510 & 49 \\
1982 & 1423 & 173 & 306 & 1813 & 807 & 137 \\
1983 & 794 & 122 & 141 & 2058 & 508 & 23 \\
1984 & 1232 & 171 & 243 & 1750 & 673 & 145 \\
1985 & 1041 & 168 & 184 & 1835 & 650 & 39 \\
1986 & 1005 & 143 & 197 & 1931 & 630 & 35 \\
1987 & 1040 & 133 & 219 & 1974 & 629 & 60 \\
1988 & 1011 & 127 & 220 & 1869 & 611 & 54 \\
1989 & 723 & 119 & 123 & 1866 & 460 & 20 \\
1990 & 1144 & 142 & 243 & 1825 & 609 & 150 \\
1991 & 1028 & 167 & 177 & 1597 & 646 & 37 \\
Average recharge for the years considered & & & 80 \\
\hline
\end{tabular}


Using the soil water budget model shown in Fig. 2, recharge was estimated for both study locations for different lengths of time periods [ie for Angunakolapelessa the durations were one year, 3 years, 5 years, 7 years and so on and for Silsoe the lengths of time periods were one year, 4 years, 8 years and so on. Fig. 3(a) shows the estimates of recharge for Angunakolapelessa for time periods of one year and Fig. 3(b) shows the estimates of recharge for time periods of 3 years (i.e., for 1976,1977 \& 1978 and 1977, 1978 \& 1979 and so on). Fig. 3(c), 3(d) and 3(e) show the estimates of recharge if the time period is considered as 5, 7 and 9 years respectively. From Fig. 3(a) the estimate of recharge could vary from about 20 to $150 \mathrm{~mm} / \mathrm{y}$, based on a time period of one year. When the time period is increased, this variation is reduced as shown in Fig. 3 (b), (c), (d) and (e) and as shown in Fig. 5. Similarly, Fig. 4 (a), (b), (c), (d) and (e) show the estimates of recharge for Silsoe with time periods of one year, 4 years, 8 years, 12 years and 16 years respectively. Here again, (as summarised in Fig. 6) the variation of the recharge estimate is high if the time period is one year, and the variation is reduced when longer time periods are used in the soil water budget.

Table 4 shows that the lowest recharge $(20 \mathrm{~mm} / \mathrm{y})$ was in 1989 and the highest recharge $(150 \mathrm{~mm} / \mathrm{y})$ was in 1977 at Angunakolapelessa. Table 6 shows a similar result for Silsoe; the lowest recharge of $17 \mathrm{~mm} / \mathrm{y}$ was in 1964 and the highest recharge of $241 \mathrm{~mm} / \mathrm{y}$ was in 1979. Fig. 5 and Fig. 6 show the ranges of recharge obtained if different time periods are considered at Angunakolapelessa and Silsoe. It is seen from Fig. 5 and Fig. 6 that it is not possible to decide on a suitable (optimum) time duration (in a soil water budget) for a particular location.

Table 5: Estimates of recharge at Angunakolapelessa for the driest (1989), wettest (1982) and an average year (1987)

\begin{tabular}{lcccccr}
\hline Year & $\begin{array}{c}\text { P } \\
(\text { rain }) \\
(\mathrm{mm})\end{array}$ & $\begin{array}{c}\text { Interception } \\
(\mathrm{mm})\end{array}$ & $\begin{array}{c}\text { Run } \\
\text { off } \\
(\mathrm{mm})\end{array}$ & $\begin{array}{c}\text { ETp } \\
(\mathrm{mm})\end{array}$ & $\begin{array}{c}\text { ETa } \\
(\mathrm{mm})\end{array}$ & $\begin{array}{r}\text { Total } \\
\text { Recharge } \\
(\mathrm{mm})\end{array}$ \\
\hline 1989 & 723 & 119 & 123 & 1866 & 460 & 20 \\
1982 & 1423 & 173 & 306 & 1813 & 807 & 137 \\
1987 & 1040 & 133 & 219 & 1974 & 629 & 60 \\
\multicolumn{2}{l}{ Average recharge for the years considered }
\end{tabular}

Table 5 shows the estimates of recharge for the wettest (1982), driest (1989) and an average year of rain (1987) during the time period considered (i.e., from 1976 - 1991) for Angunakolapelessa. At the bottom of Table 5, the average recharge value obtained by considering only these 3 years (ie the wettest, driest and an average year) are shown, which is remarkably close to the average of the estimate of recharge in Table 4. Similarly, Table 6 shows the estimates of recharge for Silsoe with the 
time duration considered as one year (with an average recharge of $116 \mathrm{~mm} / \mathrm{y}$ ) and Table 7 shows the estimates of recharge for the wettest (1964), driest (1979) and an average year (1980) for Silsoe (with an average recharge of $124 \mathrm{~mm} / \mathrm{y}$ ). As seen from these two tables (ie Tables $6 \& 7$ ) the two average estimates of recharge obtained by considering a full 25 years (in Table 6) and by just considering 3 years (in Table 7) are similar.
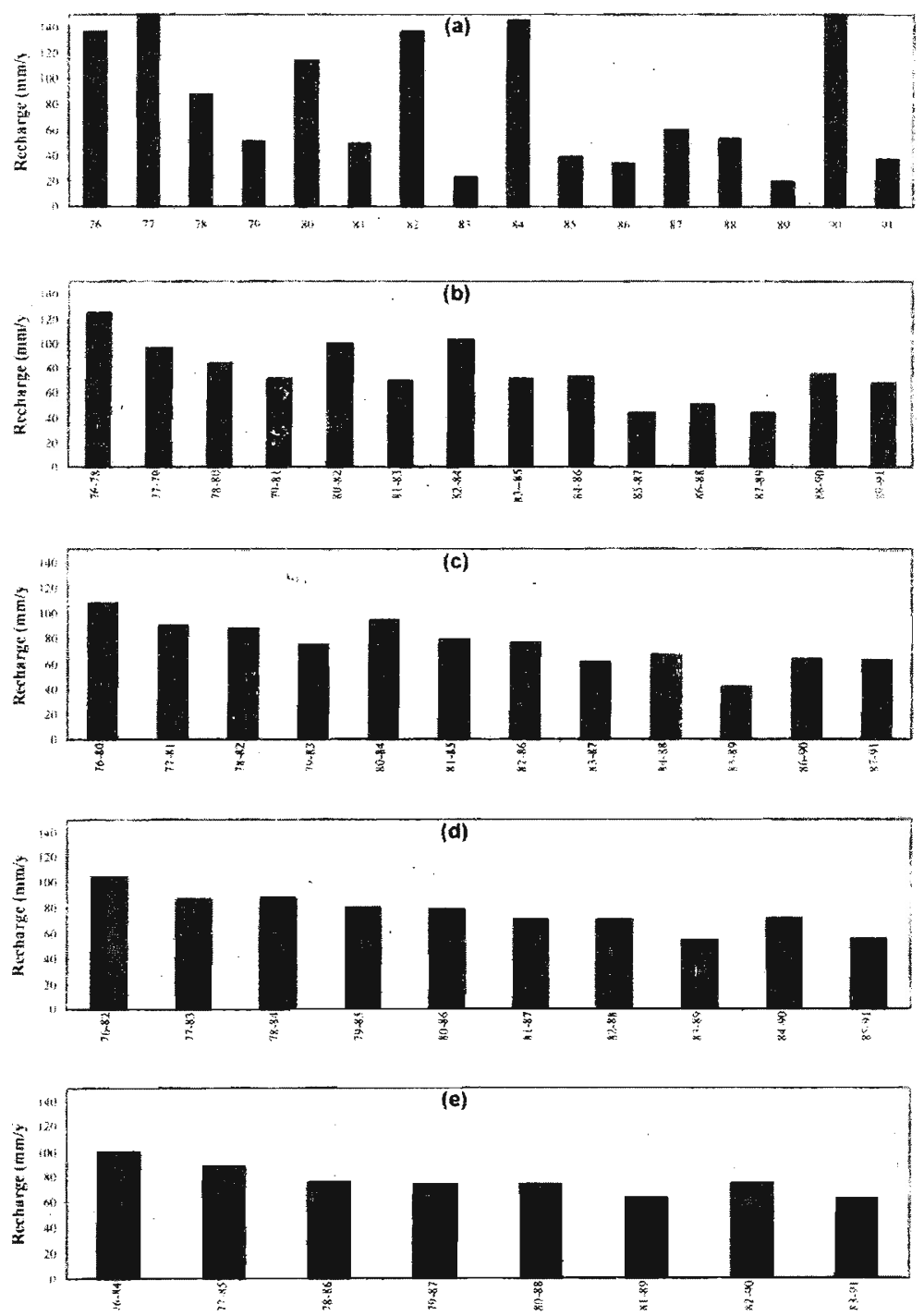

Figure 3: Estimates of recharge for different lengths of time periods in the soil water budget at Angunakolapelessa, Sri Lanka [length of time period considered in the soil water budget is (a) one year, (b) 3 years (c) 5 years (d) 7 years (e) 9 years] 

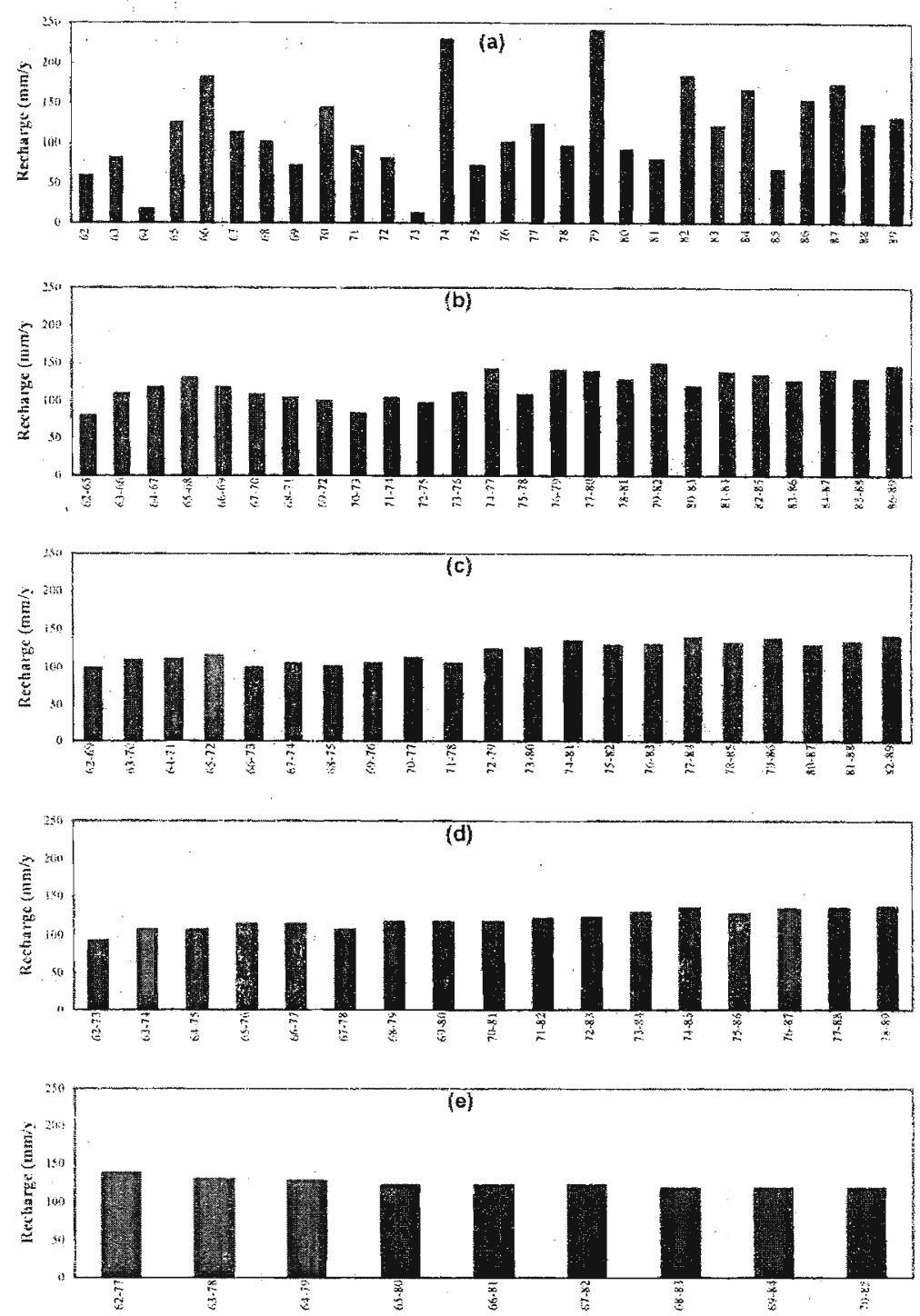

Figure 4: Estimates of recharge for different lengths of time periods in the soil water budget at Silsoe, Bedfordshire, UK [length of time period considered in the soil water budget is (a) one year, (b) 4 years (c) 8 years, (d) 12 years (e) 16 years]

From the above discussion, it is clear that one is not able to conclude that to estimate recharge at a particular location with a soil water budget, consideration of a certain number of years of climatic data is sufficient. As shown, climatic data of as many years as possible need to be considered if reasonably true values are to be obtained. Considering the results of Tables 5 and 7 (and comparing the results of Table 4 and Table 6 respectively), it is also reasonable to conclude that in situations 
where a number of years of climatic data cannot be considered, at least a wet, dry and an average year need to be considered in a soil water budget to estimate recharge.

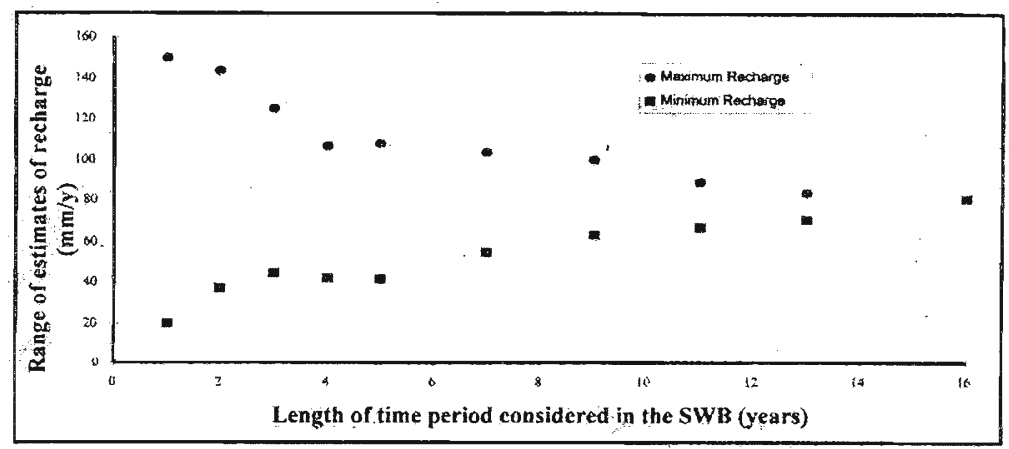

Figure 5: Range of estimates of recharge for different time periods considered in the soil water balance at Angunakolapelessa

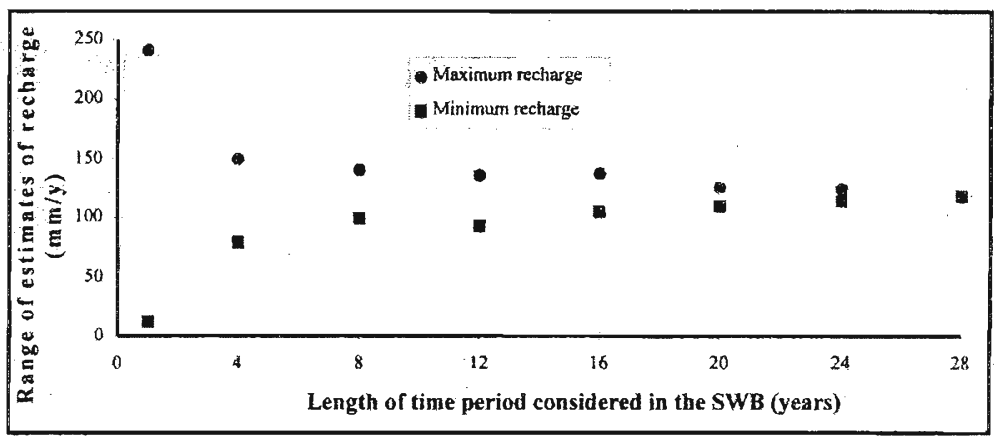

Figure 6: Range of estimates of recharge for different time periods considered in the soil water balance at Silsoe

Table 7: Estimates of recharge at Silsoe for the driest (1964), wettest (1979) and an average year (1980)

\begin{tabular}{lcccccc}
\hline Year & $\begin{array}{c}\text { Precipitation } \\
(\mathrm{mm})\end{array}$ & $\begin{array}{c}\text { Interception } \\
(\mathrm{mm})\end{array}$ & $\begin{array}{c}\text { Run } \\
\text { off } \\
(\mathrm{mm})\end{array}$ & $\begin{array}{c}\text { ETp } \\
(\mathrm{mm})\end{array}$ & $\begin{array}{c}\text { ETa } \\
(\mathrm{mm})\end{array}$ & $\begin{array}{c}\text { Total } \\
\text { Recharge } \\
(\mathrm{mm})\end{array}$ \\
\hline 1964 & 402 & 28 & 0 & 549 & 357 & 17 \\
1979 & 708 & 37 & 0 & 575 & 430 & 241 \\
1980 & 578 & 33 & 0 & 516 & 432 & 113 \\
\multicolumn{2}{l}{ Average recharge for the years considered }
\end{tabular}


Table 6: Yearly estimates of recharge for Silsoe for the period 1962-1989

\begin{tabular}{|c|c|c|c|c|c|c|}
\hline Year & $\begin{array}{c}\text { Precipitation } \\
(\mathrm{mm}) \\
\end{array}$ & $\begin{array}{c}\text { Interception } \\
(\mathrm{mm})\end{array}$ & $\begin{array}{c}\text { Run } \\
\text { off } \\
(\mathrm{mm})\end{array}$ & $\begin{array}{l}\text { ETp } \\
(\mathrm{mm}) \\
\end{array}$ & $\begin{array}{c}\mathrm{ETa} \\
(\mathrm{mm}) \\
\end{array}$ & $\begin{array}{r}\text { Total } \\
\text { Recharge } \\
(\mathrm{mm}) \\
\end{array}$ \\
\hline 1962 & 453 & 28 & 0 & 500 & 365 & 60 \\
\hline 1963 & 505 & 34 & 0 & 490 & 390 & 82 \\
\hline 1964 & 402 & 28 & 0 & 549 & 357 & 17 \\
\hline 1965 & 593 & 36 & 0 & 485 & 431 & 126 \\
\hline 1966 & 674 & 38 & 0 & 494 & 454 & 183 \\
\hline 1967 & 578 & 33 & 0 & 516 & 432 & 113 \\
\hline 1968 & 577 & 36 & 0 & 473 & 440 & 102 \\
\hline 1969 & 465 & 32 & 0 & 512 & 360 & 73 \\
\hline 1970 & 568 & 33 & 0 & 535 & 390 & 145 \\
\hline 1971 & 522 & 26 & 0 & 510 & 400 & 96 \\
\hline 1972 & 460 & 32 & 0 & 528 & 345 & 83 \\
\hline 1973 & 414 & 26 & 0 & 408 & 377 & 12 \\
\hline 1974 & 694 & 34 & 0 & 560 & 430 & 229 \\
\hline 1975 & 457 & 30 & 0 & 631 & 353 & 73 \\
\hline 1976 & 429 & 27 & 0 & 662 & 300 & 102 \\
\hline 1977 & 576 & 36 & 0 & 549 & 416 & 124 \\
\hline 1978 & 532 & 33 & 0 & 554 & 401 & 98 \\
\hline 1979 & 708 & 37 & 0 & 575 & 430 & 241 \\
\hline 1980 & 584 & 33 & 0 & 558 & 458 & 93 \\
\hline 1981 & 558 & 34 & 0 & 541 & 443 & 81 \\
\hline 1982 & 655 & 34 & 0 & 596 & 437 & 184 \\
\hline 1983 & 537 & 31 & 0 & 504 & 384 & 121 \\
\hline 1984 & 584 & 31 & 0 & 502 & 387 & 166 \\
\hline 1985 & 504 & 33 & 0 & 473 & 405 & 67 \\
\hline 1986 & 575 & 36 & 0 & 491 & 386 & 153 \\
\hline 1987 & 658 & 36 & 0 & 460 & 449 & 173 \\
\hline 1988 & 606 & 33 & 0 & 539 & 448 & 125 \\
\hline 1989 & 520 & 26 & 0 & 604 & 361 & 132 \\
\hline \multicolumn{6}{|c|}{ Average recharge for the years considered } & 116 \\
\hline
\end{tabular}




\section{CONCLUSION}

In estimating recharge with a soil water budget in a particular location, climatic data for as many years as possible should be used for the location considered. As has been done in many studies, considering just one year's data (or even 2-3 years of data) will certainly not be sufficient and will lead to recharge estimates which can vary significantly. However, if this is not possible for some reason (for example, limited data availability or non availability of suitable computing capabilities), then at least a wet, dry and an average (normal) year (with respect to mean annual rainfall) must be considered in estimating recharge with the soil water budget method. The final value of recharge may be taken as the average of the recharge estimates for these wet, dry and the normal year.

\section{References}

1 Rushton K. R. \& Ward C. (1979). The Estimation of Groundwater Recharge. Journal of Hydrology, 41: 345-361.

2 Allison G. B., Gee G. W. \& Tyler S. W. (1994). Vadose-Zone Techniques for Estimating Groundwater Recharge in Arid and Semiarid Regions. Soil Science Society of America Journal, 58: 6-14.

3 De Silva R. P., (1998). A review of the methods of estimating groundwater recharge in relation to the dry zone of Sri Lanka. The Open University Review of Engineering Technology Journal, Vol : 4(2): 3-12, Open University of Sri Lanka.

4 Gee G. W. \& Hillel D. (1988). Groundwater Recharge in Arid Regions : Review and Critique of Estimation Methods. Hydrological Processes, 2: 255-266.

5 Lerner D. N., Issar A. S. \& Simmers I. (1990). Groundwater Recharge : A Guide to Understanding \& Estimating Natural Recharge. International Association of Hydrogeologists, Hannover.

6 Howard K. W. F. \& Lloyd J. W. (1979). The Sensitivity of Parameters in the Penman Evaporation Equations and Direct Recharge Balance. Journal of Hydrology, 41: 329-344.

$7 \quad$ De Silva R. P. (1996). Estimating Groundwater Recharge with Limited Resources, with Special Emphasis on Spatial Variability: A Study in the Dry Zone of Sri Lanka. Unpublished PhD Thesis, Silsoe College, Cranfield University, UK.

8 Doorenbos J. \& Pruitt W. O. (1977). Crop Water Requirements. FAO, Rome. 
9 Dharmasiri J. K. \& Dharmawardena K. G. (1980). Recharge Measurements Using Tritium Tracer at Different Sites in Sri Lanka. Interamerican Symposium on Isotope Hydrology, Bogota, Columbia.

10 Irving W. M. (1982). Chloride Ion Concentration as an Aid to Estimating Recharge to the Woburn Sands. Quarterly Journal of Engineering Geology, 15: $47-54$. 